\title{
A PROPOSAL OF DEFINING PARTICIPANT PREFERENCES IN A DECISION AIDING PROCESS WITH THE PARTICIPANT REPRESENTING A COLLECTIVE BODY
}

\author{
Tomasz Thiel \\ Institute of Structural Engineering, Division of Construction Engineering and Management, \\ Poznan University of Technology, Piotrowo 5, 60-965 Poznan, Poland \\ E-mail: tomasz.thiel@ikb.poznan.pl
}

Received 12 December 2005; accepted 15 September 2006

\begin{abstract}
This paper presents a proposal of defining threshold functions reflecting preferences of a chosen participant in the decision aiding process applied to calculation ELECTRE III method. The decision problem touched valuation scenarios of the development of the mass transit system. The participant in the decision process was a collective body. It was not a very numerous group of representatives (just over a dozen people) of the company management - the Municipal Transport Company.
\end{abstract}

Keywords: multiple criteria decision aiding, Electre III method, participant in the process of decision aiding, a group of representatives, proposal of defining threshold functions.

\section{Introduction}

The paper presents a proposal which highligts a way of defining values of parameters reflecting preferences of a participant in the process of decision aiding, whereas the participant is a collective body - a set (group) of representatives. The issue has been presented in view of a decision aiding process, in which the author played the part of an analyst. The decision aiding problem touched upon a number of different variants, i.e. scenarios of the development of a mass transit system in one of the Polish cities. The Town Hall was the ultimate decision maker. The remaining participants represented passengers (a very numerous group), and the representatives of public transport services provider (operator) - the Municipal Transport Company (more than ten representatives of the company management). The aim of the multiple-criteria analysis, which used the chosen MCDA methodology (ELECTRE III method) was to arrive at a model of preferences for each group of representatives, to carry out calculations which would point at the ranking of the compared variants separately for each group of representatives, and to suggest a compromise variant, acceptable for both groups, the decision maker. The manner of calculating parameters reflecting preferences of the decision aiding process, in keeping with
ELECTRE III method, has been defined at the stage of indicating the parameters. Nonetheless, already at that stage certain doubts appeared whether or not the selected manner was the most appropriate. Consequently, further attempts to identify a more universal approach to calculating those parameters had been made.

\section{A description and manner of solving a decision aiding problem [1]}

\subsection{Accepted variants - scenarios for the development} of the mass transit system

Firstly, A-0 scenario (variant) which had been identified, was the one which served the role of a reference (the current status). It reflected the condition, processes involved, and public transport policy which had been passive from the viewpoint of investments. Apart from the above mentioned variant, three additional variants were identified: variant (scenario) A - Optimum, variant (scenario) A Maximum, and variant (scenario) A - Minimum.

Variant A - Optimum. More than anything else, it included modernization and implementation of better solutions to tram transport, and designing an optimum arrangement for bus transport (lower transportation volume). This 
was the variant with the most radical transformations.

Variant A - Maximum also included the modernization and implementation of better solutions to tram transport and the development of bus transport in town. The role of a bus as a means of transport was the biggest, in comparison with the remaining variants.

Variant A - Minimum also included the modernization and implementation of better solutions to tram transport, though limiting the role of bus transport to bare minimum. It was an attempt of tram and train transport taking over major streams of commuters.

The plans of development of municipal system of the mass transit system consisted of a set of variants which had to be compared, matched against each other, and assessed in accordance with the assumed criteria of evaluation.

\subsection{Criteria assumed to the evaluation of variants}

As a result of appropriate analyses, a family of criteria has been arrived at, thanks to which the assessment of variants under discussion regarding public transport systems was possible. Those criteria were as follows:

- waiting time [min],

- riding time [min],

- timeliness [a number of delays per 1000 rides],

- reliability [a number of rides which were cancelled per 1000 rides],

- $\quad$ situational safety [a number of hazards per 100 rides],

- transferring frequency [a number of rides/ a number of travels],

- comfort of travel [\% of comfortable rides - no overcrowding, and in low floor vehicles]

- financial efficiency [\% ratio of expenditure to cost],

- investment profitability [\%-IRR] (exclusively in view of estimation in accordance with the model preferred by operator).

\subsection{Assuming a calculation method}

The analysis of criteria occurring in the decision related problem under consideration indicated that the simplest model reflecting the preferences of both groups of participants, with respect to every criterion separately, will be a model utilizing threshold functions - a pseudo-criterion model, alongside with providing information regarding relative importance of individual criteria (the weights of criteria) [2 and 3]. The mentioned model is a non-compensation model [4] which, to a great extent, makes it easy to reflect the preferences of participants in the decision aiding process. The method which meets the above mentioned expectations is ELECTRE III. That is why it has been chosen to conduct calculation experiments. The description of the method can be also found in [3].

\subsection{Defining a preference model for a selected participant in a decision aiding process}

Having selected a calculation method, it was necessary to define a model of preferences for representatives of public transport services provider, and for the representatives of passengers. Within the framework of ELECTRE III, the set of data reflecting preferences is as follows: relative importance of criteria, and threshold functions allowing to define the following thresholds: indifference q, preference $-p$ and veto $-v$. All the data which helped define the preferences of both participants were collected from a survey using questionnaires. The article presents the results arrived at with respect to representatives of an operator who are not numerous - just over a dozen people. The presentation of the analysis of the results, and a proposal of how to define the values of parameters reflecting the preferences of passengers who represent a numerous group of people, will be offered in a separate publication.

The values of relative importance of the criteria were obtained basing on the first questionnaire, where the representatives of passengers and representatives of an operator defined their expectations and requirements with respect to the municipal system of public transport. Those values were calculated as arithmetic mean, rounded up to 0,5 , and presented in Table 1.

The remaining data which facilitate defining the thresholds of indifference, preference, and veto, had been arrived at following the completion of the second questionnaire. In the questionnaire, separately for each criterion, every respondent stated the differences in changes of values, depicting them as insignificant, of little significance, quite significant, and extremely significant. In order to assume the threshold values of $q, p$, and $v$, the procedure was as follows:

- the indifference threshold was calculated as a weighted mean for a number of responses where the participants of the survey stated the biggest difference between values (separately for each criterion), for which the change in value was completely insignificant, and for the number of responses in which the participants of the survey stated the least difference, for which a change in value had little significance. In the instances, where the participants of the survey, for the least difference declared the difference as extremely significant, threshold q was defined as $q=0$.

- the preference and veto thresholds were calculated as a weighted mean for a number of responses where the participants of the survey stated the least difference at which a change in value (for a given criterion) was quite significant (it was a basis for calculating preference threshold) or extremely significant (it was a basis for calculating veto threshold). 
Values arrived at in the depicted manner are presented in Table 1.

\section{A proposal regarding the manner of defining the value of parameters reflecting preferences of a participant in a decision aiding process represented by a number of representatives consisting of a small group}

The author would like to present his own proposal of defining threshold functions - the values of thresholds (when they are constant) for $q, p$, and $v$ thresholds. In the survey mentioned in section 2.4 , different values have been provided for every criterion, with regard to which the respondent stated (taking his or her individual preferences into account) whether, from his or her point of view, they were completely insignificant of little significance, quite significant, or extremely significant (taking the compared variants under consideration). Thus, the representatives of a public transport services provider, who can be described as experts, had not given those values directly (unsolicited). The problem was as follows: how, basing on the information from surveys, was it possible to define the values of $q, p$, and $v$ thresholds ? In order to do this, it was assumed that the indifference threshold q could be defined as the biggest difference of values for which the situation whereby it is of no significance at all will occur. Then, it will be the value of the threshold which can be defined as $q_{\min }$. Another basis for accepting $q$ threshold may consist of the least difference of values for which the situation depicted as it is of little significance will occur. The value of the threshold arrived at in this manner can be defined as $q_{\max }$. It is also possible to assume that the value of this threshold will be found between the value of $q_{\text {min }}$, for which the situation depicted as yet of little significance will occur, and the value of $q_{\text {max }}$, for which the situation depicted as now of little significance. In such a case, it is safe to assume that, for example, the value of $q$ threshold will be placed in the middle of the range of $<q_{\min } ; q_{\max }>$, in other words, $q_{\text {me }}$ will be calculated as an arithmetic mean.

It is possible to use a similar approach to define thresh- olds $\mathrm{p}$ and $\mathrm{v}$. As to threshold $\mathrm{p}$, definition of values of $p_{\min }$ and $p_{\max }$ was obtained on the basis of the biggest difference of values for which still a situation whereby it is of little significance $\left(p_{\min }\right)$, and on the basis, respectively, of the smallest difference of values for which a situation whereby it is if great significance will occur $\left(p_{\max }\right)$. Similarly as in the case of threshold q, it could be assumed that the value of threshold $\mathrm{p}$ would be found in the middle of the range of $<p_{\min } ; p_{\max }>$, in other words, $p_{\text {me }}$ would be calculated as an arithmetic mean. As to threshold $\mathrm{v}$, defining the value of $v_{\min }$ would be based on the biggest difference in values, for which still the situation whereby it is extremely significant $\left(v_{\min }\right)$ will occur. On the other hand, the value of $v_{\max }$ threshold, would be arrived at for the smallest difference in values, for which the situation whereby it is extremely significant will already occur. In case of this threshold, it is also safe to assume that the value of threshold $v$ would be found in the middle of the range of $\left\langle v_{\min } ; v_{\text {max }}>\right.$, in other words, $v_{\text {me }}$ would be calculated as an arithmetic mean value.

Such a procedure should be implemented for every criterion.

Within the framework of defining the values of thresholds $q, p$, and $v$ (when the values were not provided directly by the subjects of the survey), it was possible - for each of the thresholds - to take into consideration the minimum values $\left(q_{\min }, p_{\min }, v_{\min }\right)$, the maximum values $\left(q_{\max }\right.$, $\left.p_{\max }, v_{\max }\right)$, or any value from the range of: $\left(q_{\min } ; q_{\max }\right)$ for threshold $q ;\left(p_{\min } ; p_{\max }\right)$ for threshold $\mathrm{p}$, and $\left(v_{\min } ; v_{\max }\right)$ for threshold $v$.

Assuming that the value for each of the thresholds (q, p, and $v$ ) will be found within a certain range, we may arrive at the scope of variation for a particular threshold. It may be a basis for performing a sensitivity analysis for the thresholds with respect to the final result obtained through the assumed calculation method. An example of such an analysis has been presented by the author [5 and 6].

Another issue is to assume the values of thresholds $q$, $p$, and $v$, taking into consideration the results of all surveys. Remembering the fact that the number of the survey participants was a small sample (casting off the questionnaires which were incorrectly filled in, the remaining number which

Table 1. Information on preferences of representatives of an operator gathered according to the manner described in section 2.4.

\begin{tabular}{|l|c|c|c|c|}
\hline \multicolumn{1}{|c|}{ Evaluation criteria } & $\begin{array}{c}\text { Indifference } \\
\text { threshold }\end{array}$ & $\begin{array}{c}\text { Preference } \\
\text { threshold }\end{array}$ & $\begin{array}{c}\text { Veto } \\
\text { threshold }\end{array}$ & $\begin{array}{c}\text { Relative importance of } \\
\text { criteria }\end{array}$ \\
\hline 1) waiting time & 0,5 & 4,3 & 7,0 & 8,1 \\
\hline 2) riding time & 0,7 & 4,0 & 9,4 & 8,4 \\
\hline 3) timeliness & 10 & 60 & 118 & 9,6 \\
\hline 4) reliability & 1,0 & 4,4 & 7,8 & 8,9 \\
\hline 5) situational safety & 0,4 & 1,4 & 3,3 & 8,1 \\
\hline 6) transferring frequency & 0,005 & 0,029 & 0,076 & 6,1 \\
\hline 7) comfort of travel & 3,5 & 7,8 & 8,0 & 5,6 \\
\hline 8) financial efficiency & 1,0 & 3,5 & 8,2 & 6,0 \\
\hline 9) investment profitability & 1,0 & 6,1 & 17,5 & 6,0 \\
\hline
\end{tabular}


was taken into account was 8 questionnaires), it was suggested that defining the maximum and minimum values for each threshold should be done on the basis of the mean value from that number of questionnaires which had been completed correctly. The calculations will be performed for $q_{\min }, q_{\max }, p_{\min }, p_{\max }, v_{\min ,}$ and $v_{\max }$, separately for each criterion.

Fig 1 shows the results of correctly completed questionnaire forms for a given criterion: waiting time at the bus and tram stops.

Basing on those results, threshold values for $q, p$, and $v$ have been calculated, according to the manner proposed by the author. As to $q$, the indifference threshold, the calculated values were as follows: $q_{\min }=0,5$ [min], $q_{\max }=1,3$ [min], $q_{\mathrm{me}}=0,9$ [min]. As to $\mathrm{p}$, the preference threshold, the results were as follows: $p_{\min }=1,9[\mathrm{~min}], p_{\max }=4,3[\mathrm{~min}], p_{\mathrm{me}}=3,1$ [min]. As to $v$, the veto threshold, the results were as fol- lows: $v_{\min }=4,6[\mathrm{~min}], v_{\max }=8,9[\mathrm{~min}], v_{\operatorname{me}}=6,8$ [min]. Using the same procedure, for each of the remaining criteria, ranges of values and mean values of $q, p$, and $v$ thresholds were calculated. The values are presented in Table 2 .

When the values of $q_{\min }, q_{\mathrm{max}}, q_{\mathrm{me}}, p_{\min }, p_{\mathrm{max}}, p_{\mathrm{me}}, v_{\mathrm{min}}$, $v_{\max }$, and $v_{\text {me }}$ for all criteria have been calculated, further procedure can be as follows:

- one should aim at assuming a specific value for each of the thresholds, taking into consideration the answers provided by the survey participants, and the values taken by the criteria in the compared variants. As far as the analysed decision related problem, the analysis of survey results (the number of questionnaires was a small sample) should be limited to drawing logical conclusions. As to the selected criterion (waiting time at the bus and tram stops criterion [min]), it could be assumed that q threshold

a) data in order to define $q$ threshold

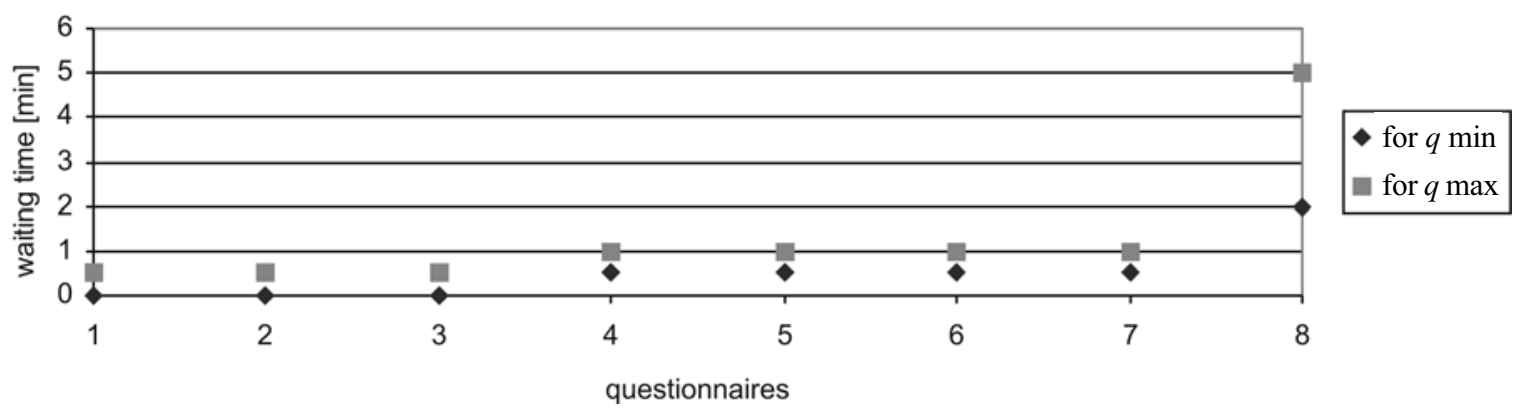

b) data in order to define $p$ threshold

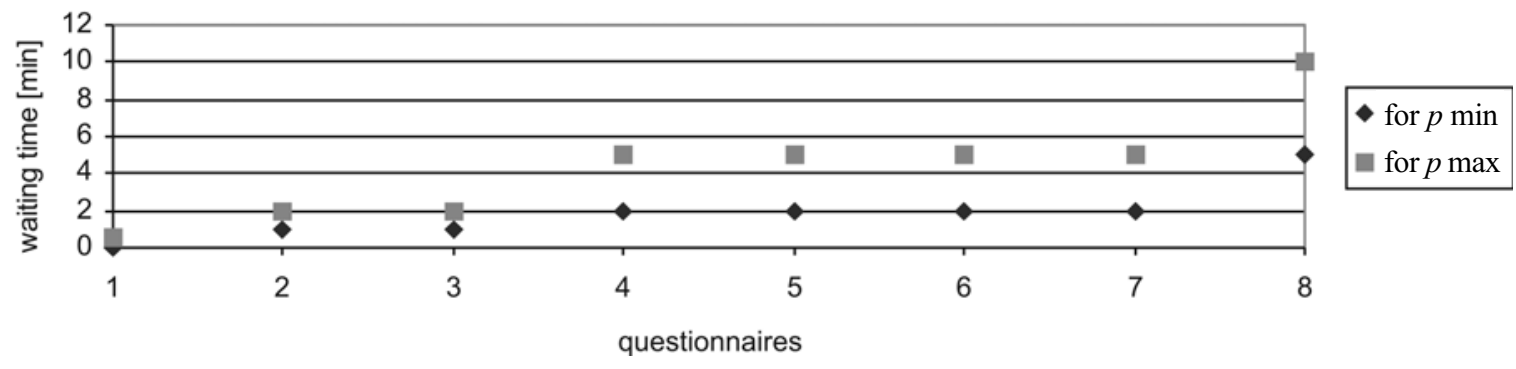

c) data in order to define $v$ threshold

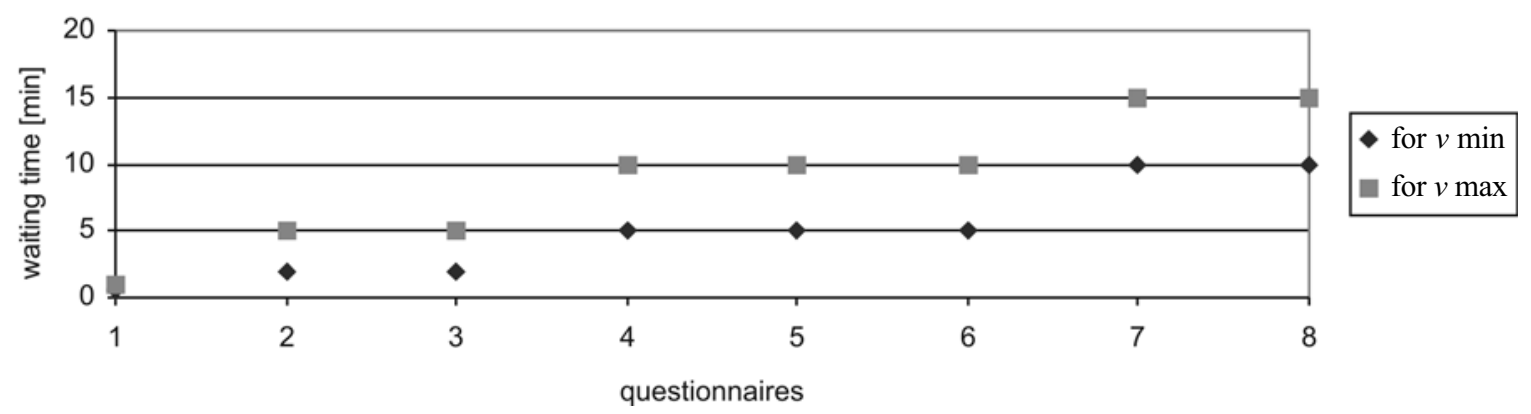

Fig 1. Results of questionnaires completed by the representatives of a public transport services provider regarding waiting time at the bus and tram stops criterion [min], in order to define a) $q$ threshold; b) $p$ threshold, and c) $v$ threshold 
Table 2. Values of $q, p$, and $v$ thresholds, calculated according to the author's proposal

\begin{tabular}{|c|c|c|c|}
\hline Evaluation criteria & $\begin{array}{c}\text { Indifference } \\
\text { threshold } \\
q_{\min } q_{\max } q_{\mathrm{me}}\end{array}$ & $\begin{array}{c}\text { Preference } \\
\text { threshold } \\
p_{\min } p_{\max } p_{\text {me }}\end{array}$ & $\begin{array}{c}\text { Veto } \\
\text { threshold } \\
v_{\min } v_{\max } v_{\text {me }}\end{array}$ \\
\hline 1) waiting time & $\begin{array}{lll}0,5 & 1,3 & 0,9\end{array}$ & $1,9 \quad 4,3 \quad 3,1$ & $\begin{array}{lll}4,6 & 8,9 & 6,8 \\
\end{array}$ \\
\hline 2) riding time & $\begin{array}{lll}0,5 & 1,6 & 1,1 \\
\end{array}$ & $2,0 \quad 4,0 \quad 3,0$ & $\begin{array}{lll}7,4 & 10,0 & 8,7 \\
\end{array}$ \\
\hline 3) timeliness & $\begin{array}{lll}6 & 21 & 13,5 \\
\end{array}$ & $\begin{array}{lll}33 & 60 & 46 \\
\end{array}$ & $\begin{array}{lll}75 & 149 & 112 \\
\end{array}$ \\
\hline 4) reliability & $\begin{array}{lll}0,75 & 1,75 & 1,35 \\
\end{array}$ & $\begin{array}{lll}2,6 & 5,0 & 3,8 \\
\end{array}$ & $\begin{array}{lll}7,6 & 10,3 & 8,9 \\
\end{array}$ \\
\hline 5) situational safety & $0,1 \quad 0,05$ & $0,5 \quad 1,4 \quad 0,95$ & $2,0 \quad 4,0 \quad 3,0$ \\
\hline 6) transferring frequency & $0,1 \quad 0,6 \quad 0,4$ & $\begin{array}{lll}0,7 & 1,9 & 1,3 \\
\end{array}$ & $3,6 \quad 6,6 \quad 5,1$ \\
\hline 7) comfort of travel & $\begin{array}{lll}0,75 & 3,1 & 1,95 \\
\end{array}$ & $\begin{array}{lll}4,9 & 7,3 & 6,1 \\
\end{array}$ & $\begin{array}{lll}8,7 & 14,6 & 11,7 \\
\end{array}$ \\
\hline 8) financial efficiency & $\begin{array}{lll}0,25 & 0,9 & 0,6 \\
\end{array}$ & $\begin{array}{lll}1,6 & 3,5 & 2,6 \\
\end{array}$ & $\begin{array}{lll}4,8 & 8,1 & 6,4 \\
\end{array}$ \\
\hline 9) investment profitability & 0,6 & $\begin{array}{lll}2,6 & 6,1 & 4,4 \\
\end{array}$ & $\begin{array}{lll}11,5 & 18,8 & 15,1 \\
\end{array}$ \\
\hline
\end{tabular}

would be close to the value of $q_{\text {min }}=0,5$ ( Fig $1 \mathrm{a}-3$ questionnaires, where the difference of value of 0,5 [min] and 4 questionnaires, where the difference of value of 1,0 [min] was of little significance), $\mathrm{p}$ threshold would come close to the value of $p_{\mathrm{me}}=3,1$ (see Fig $1 \mathrm{~b}$, it can be assumed that $\mathrm{p}$ threshold will occur in a half of the ranges, taking into consideration questionnaires 2 to 7 , and discarding two extreme questionnaires), and $v$ threshold to the value of $v_{\mathrm{me}}=6,8$ (see Fig $1 \mathrm{c}-$ in case of 7 questionnaires the differences in values for waiting time at 2,5 , and 10 [min] are still very significant, whereas the differences at the range of 5, 10, and 15 [min] are extremely significant. Therefore, it can be assumed that $\mathrm{v}$ threshold will occur in a half of the ranges: 2 and 5 [min], 5 and 10 [min], and 10 and 15 [min]). Thresholds for remaining criteria can be defined in a similar manner.

- one should avoid ascribing specific values to thresholds $q, p$, and $v$, but basing on the minimum and maximum values calculated beforehand, and possibly taking into account also mean values, one should analyse the impact of changes of those parameters on the final result. It will be the sensitivity analysis of the final result. The procedure is more troublesome for the analyst, but it results in the increased credibility of the result [5 and 6]. It should be stressed that minimum and maximum thresholds reflect the divergence of preferences in the surveyed group (representatives of an operator).

Completing the calculations using the assumed method (ELECTRE III) and the analysis of the results is the last stage of the decision aiding process.

\section{Conclusions}

The analysis of the decision aiding problem related to the development of the mass transit system, which participants, apart from the analyst, were the representatives of a transport services provider and passengers, led to formulating the following conclusions:
1. In order to avoid ambiguities, all data consisting of building blocks for the definition of the model of preferences of the participants in the decision process who form a collective body (a set of representatives), should be acquired at the stage at which all values for criteria defining the compared variants are already clear.

2. In the context of a group of representatives, who may be recognized as experts (in the framework of the analysed decision aiding problem, those are representatives of the operator) being part of the decision aiding process, in order to define the values of parameters reflecting the preferences of that participant, it is safe to assume that the values of the parameters (for example, $q, p$ and $v$ thresholds in the discussed case) will be submitted directly by those completing the questionnaires. It is necessary to explain to the survey participants the nature and significance of the parameters. If, for technical, time span, or other reasons the procedure is impossible to implement, what remains is the solution put forward by the author in section 3 of the article.

3. There is a positive aspect of defining preferences of the participant in the decision aiding process represented by a set of representatives (in the discussed case - representatives of the operator), using the solution put forward in section 3, namely to arrive at the ranges of variation of parameters reflecting preferences of the participant. It defines the scope, and consists of a basis for sensitivity analysis of the influence of changes in values of the parameters on the final result.

4. The question of defining a model of preference of the participant in the decision aiding process while the participant is a collective body, or represents a large number, is very complex. It requires individual approach, as a result of the following: a specific character of the decision aiding problem, availability of contact with representatives of participants of the process, understanding of the role they play, and involvement at the stage of providing the required information. In case of the set of representatives judged as a large sample, it is possible to additionally apply statistical reasoning. 


\section{References}

1. Zak, J.; Thiel, T. Multiple Criteria Evaluation of the Development Scenarios of the Mass Transit System. CD-ROM - 9th WCTR World Conference on Transport Research, COEX Convention Center, Seoul, Korea, July 22-27, 2001.

2. Roy, B. Methodology of multi-criteria decision aiding process (Methodologie Multicritere d'Aide a la Decision). Economica, Paris, 1985 (in French).

3. Skalka, J. M.; Bouyssou, D. and Vallee, D. Methodical aspects of ELECTER III and IV and guide of use (ELECTER III et IV aspects metodologiques et guide d'utilisation), Document No 25, LAMSADE, Paris, 1992 (in French).
4. Bouyssou, D.; Vansnick, J. C. Noncompensatory and generalized noncompensatory preference structures. Document No 59, LAMSADE, Paris, 1985.

5. Thiel, T. Methodical aspects of multi-criteria decision aiding in civil engineering (Metodyczne aspekty wielokryterialnego wspomagania decyzji w inżynierii produkcji budowlanej). $\mathrm{PhD}$. Thesis, Poznan University of Technology, Poznan, 1996 (in Polish).

6. Thiel, T. Solution of multicriteria decision problems related to the evaluation of selected alternatives of motorway surface construction in Poland, with sensitivity and stability analysis. In: 53rd Meeting of the European Working Group Multicriteria Aid for Decisions, Athens, March 29-30, 2001.

\section{SPRENDIMŲ PRIĖMIMO PROCESO DALYVIŲ PREFERENCIJŲ NUSTATYMAS, KAI JAME DALYVAUJA BENDRĄ NUOMONE TURINTYS ASMENYS}

\section{T. Thiel}

Santrauka

Bandoma rasti naudingumo funkcijas, perteikiančias pasirinktų sprendimų prièmimo proceso dalyvių nuomonę ir naudojamas skaičiuojant ELECTRE III metodu. Suformuluota problema - įvertinti viešojo transporto sistemos plètros scenarijus. Sprendimų prièmimo proceso dalyviai buvo bendrą nuomonę turintys asmenys. Tai negausi, maždaug dvylikos žmonių grupé, dirbanti municipalinėje transporto kompanijoje.

Reikšminiai žodžiai: daugiakriterinè sprendimų parama, ELECTRE III metodas, sprendimų prièmimo paramos dalyvis, atstovu grupè, naudingumo funkcijos nustatymas.

Tomasz THIEL. Ph D. C. E., Assistant Professor, Poznan University of Technology, Institute of Structural Engineering, Division of Construction Engineering and Management. Ph D. (1997). Analyst at the stage of solving decision problems in the area of construction engineering. Research interests: decision making theory, operational research in construction, investment process, maintenance and exploitation of building structures. 